Edu Consilium: Jurnal BK Pendidikan Islam

Vol. 2, No. 2, 2021, hlm. 100 - 113

DOI: $10.1905 /$ ec.v1i1.1808

ISSN 2503-3417 (online)

ISSN 2548-4311 (cetak)

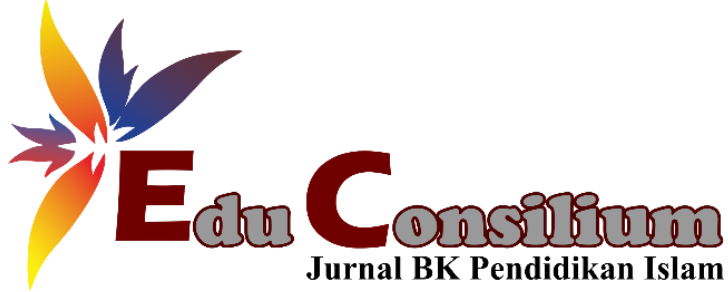

\title{
PENGARUH LAYANAN INFORMASI MELALUI DARING TERHADAP PENINGKATAN MINAT STUDI LANJUT KE PERGURUAN TINGGI PADA SISWA SMAN 3 SUKOHARJO
}

\footnotetext{
Candra Giri Murti ${ }^{1}$, Aldila Fitri Radite Nur Maynawati ${ }^{2}$, Mahmuddah Dewi Edmawati ${ }^{3}$ Program Studi Bimbingan dan Konseling FKIP Universitas Veteran Bangun Nusantara, Jl. Letjend Sujono Humardani no 01, Sukoharjo, 57521

*Mahmuddah Dewi Edmawati, mahmuddahdewi@gmail.com.
} 


\begin{tabular}{|c|c|}
\hline & Abstract \\
\hline \multirow[t]{2}{*}{$\begin{array}{l}\text { Keyword : } \\
\text { information } \\
\text { service, } \\
\text { online, } \\
\text { interest in } \\
\text { further } \\
\text { study }\end{array}$} & $\begin{array}{l}\text { This study aims to find out how the influence of online information services can } \\
\text { increase the interest of SMA N } 3 \text { Sukoharjo students to continue their studies in } \\
\text { higher education. The method in this study the researchers used quantitative } \\
\text { experimental methods. Quantitative research does not question the relationship } \\
\text { between researchers and research subjects because research results depend more on } \\
\text { the instruments used and the measurable variables used, rather than on the intimate } \\
\text { and emotional involvement between researchers and the subjects studied. The } \\
\text { results of the study were that there was a significant effect on the provision of } \\
\text { online information services to students of class XI MIPA } 3 \text { SMA Negeri } 3 \\
\text { Sukoharjo in the } 2020 / 2021 \text { academic year to continue their education to higher } \\
\text { education. The results of the study using the calculation of the Paired Sample T- } \\
\text { Test in the Pre Test and Post Test showed a significance value (2-tailed) } 0.000 \\
<0.05 \text {, meaning that there was a significant difference between the initial variable } \\
\text { and the final variable. This shows that there is a significant effect on the treatment } \\
\text { given to each variable. So it can be concluded that: "There is an influence of } \\
\text { providing online information services regarding further studies on the interest of } \\
\text { class XI MIPA } 3 \text { students at SMA Negeri } 3 \text { Sukoharjo in the } 2020 / 2021 \text { academic } \\
\text { year to continue their education to higher education. }\end{array}$ \\
\hline & Abstrak: \\
\hline $\begin{array}{l}\text { Kata Kunci: } \\
\text { layanan informasi, } \\
\text { daring, minat studi } \\
\text { lanjut }\end{array}$ & $\begin{array}{l}\text { Penelitian ini bertujuan untuk mengetahui bagaimana pengaruh layanan informasi } \\
\text { secara daring dapat meningkatkan minat siswa SMA N } 3 \text { Sukoharjo untuk } \\
\text { melanjutkan studinya ke Perguruan Tinggi. Metode dalam penelitian ini peneliti } \\
\text { menggunakan metode kuantitatif ekperimen. Penelititan kuantitatif tidak } \\
\text { mempermasalahkan hubungan antara peneliti dengan subyek penelitian karena hasil } \\
\text { penelitian lebih banyak tergantung dengan instrumen yang digunakan dan terukur } \\
\text { variabel yang digunakan, dari pada intim dan keterlibatan emosi antara peneliti } \\
\text { dengan subyek yang diteliti. Hasil penelitian adalah ada pengaruh yang signifikan } \\
\text { terhadap pemberian layanan informasi secara daring kepada siswa kelas XI MIPA } 3 \\
\text { SMA Negeri } 3 \text { Sukoharjo tahun pelajaran 2020/2021 untuk melanjutkan } \\
\text { pendidikanya ke Perguruan Tinggi. Hasil penelitian dengan menggunakan } \\
\text { perhitungan uji Paired Sample T-Test pada Pre Test dan Post Test menunjukkan } \\
\text { nilai Signifikansi ( } 2 \text {-tailed) 0,000 < 0,05, artinya menunjukkan adanya perbedaan } \\
\text { yang signifikan antara variabel awal dengan variabel akhir. Ini menunjukkan terdapat } \\
\text { pengaruh yang bermakna terhadap perlakuan yang diberikan pada masing-masing } \\
\text { variabel. Sehingga dapat disimpukan bahwa: "Terdapat pengaruh pemberian layanan } \\
\text { informasi secara daring mengenai studi lanjut terhadap minat siswa kelas XI MIPA } 3 \\
\text { SMA Negeri } 3 \text { Sukoharjo tahun pelajaran 2020/2021 untuk melanjutkan } \\
\text { pendidikanya ke Perguruan Tinggi. }\end{array}$ \\
\hline
\end{tabular}

CEdu Consilium: Jurnal Bimbingan dan Konseling Pendidikan Islam Institut Agama Islam Negeri Madura, Indonesia

\section{PENDAHULUAN}

Era perkembangan teknologi sekarang ini kesadaran tentang pentingnya pendidikan semakin tinggi. Pendidikan dapat memberikan harapan dan kemungkinan yang lebih baik di masa mendatang. Melalui pendidikan orang-orang dapat mengoptimalkan bakat dan kemampuan yang mereka miliki. Akan tetapi semua itu harus diimbangi dengan mutu pendidikan yang berkualitas. Mutu pendidikan akan mempengaruhi bagus atau tidakanya hasil yang diperoleh dari suatu pendidikan.Dalam hal ini, penyesuaian merupakan hal yang penting. Untuk mengembangkan mutu pendidikan yang berkualitas, Perguruan Tinggi 
merupakan salah satu tempat bagi siswa untuk mengembangkan ilmu pengetahuannya dan membawa siswa menuju pendidikan yang lebih baik.

Untuk melanjutkan ke Perguruan Tinggi perlu diawali dengan menumbuhkan kesukaan atau minat siswa untuk melanjutkan ke Perguruan Tinggi. Minat merupakan suatu keinginan yang dapat mendorong siswa untuk menyukai sesuatu. Dengan mengetahui bakat, minat serta potensi diri maka seseorang dapat melakukan diagnosa dan prediksi kemungkinan kesuksesan atau kegagalan seseorang dalam bidang tertentu di masa depan. Pada dasarnya prediksi adalah mempertemukan potensi seseorang dengan persyaratan yang dituntut oleh suatu lembaga/institusi (Nur'aeni, 2012).

Jika minat siswa terhadap Perguruan Tinggi sudah muncul maka siswa akan terus berusaha untuk masuk Perguruan Tinggi. Ada banyak faktor yang dapat mempengaruhi minat siswa rendah dalam memasuki Perguruan Tinggi. Salah satunya adalah kurangnya informasi atau sosialisasi tentang perguruan tinggi terhadap siswa, sehingga informasi yang didapat oleh siswa tidak optimal. Kurangnya sosialisasi dari setiap Perguruan Tinggi dapat sangat berpengaruh bagi tumbuhnya minat siswa untuk melanjutkan ke Perguruan Tinggi apalagi dalam situasi Pandemi Covid-19 seperti saat ini. Oleh karena itu, salah satu upaya yang dapat dilakukan yaitu dengan cara memberikan layanan informasi studi melalui daring atau jejaring internet menggunakan aplikasi seperti zoom, google meet, whatsapp yang dapat memberikan askes informasi cepat mulai dari Pengertian Minat, Pengertian Perguruan Tinggi, bentukbentuk Perguruan Tinggi, Jalur masuk Perguruan Tinggi, Materi tes masuk Perguruan Tinggi, dan lain-lain. Layanan informasi studi lanjut ke Perguruan Tinggi berbasis daring ini sangat penting bagi siswa untuk menumbuhkan minatnya tentang Perguruan Tinggi.

Data yang dihimpun dari Badan Pusat Statistik terkait dengan Rasio Angka Partisipasi Kasar (APK) Perempuan/Laki-Laki di Indonesia yang melanjutkan ke tingkat Perguruan Tinggi tahun 2018-2020 yakni tahun 2018 sebesar 30,19\% , tahun 2019 sebesar 30,28\% dan kemudian tahun 2020 sebesar 30,85\%. Data ini dapat menjadi acuan bahwa potensi anak Indonesia yang melanjutkan ke jenjang Perguruan Tinggi masih stabil, walaupun angkanya belum sampai $50 \%$ atau separuhnya. Namun ini menjadi bagian kerja bersama komponen bangsa untuk meningkatkan kualitas pendidikan sampai ke jenjang Perguruan Tinggi, dan sudah saatnya untuk melangkah ke program yang lebih tinggi dibanding wajib belajar dua belas tahun saja. 
Menurut Suhertina (2014) layanan informasi yaitu layanan BK yang memungkinkan siswa menerima dan memahami berbagai informasi seperti informasi pendidikan dan informasi jabatan. Informasi tentang sesuatu dapat dijadikan sebagai bahan pertimbangan dan pengambilan keputusan untuk kepentingan siswa. Hasil penelitian Novi Wahyu Hidayati dengan Judul "Pengaruh Layanan Informasi Studi Lanjut Terhadap Perencanaan Karir Siswa”. Teknik analisis data diperoleh t-hitung lebih besar dari t-tabel (10,952>2,021). Maka Ha diterima dan Ho ditolak. Hipotesis yang menyatakan "terdapat perbedaan yang signifikan dalam perencanaan karir antara sebelum dan sesudah penerapan layanan informasi studi lanjut", dapat diterima. Maka dapat disimpulkan bahwa ada pengaruh yang positif dengan pemberian layanan informasi studi lanjut terhadap perencanaan karir siswa, dan implementasi dari layanan informasi studi lanjut ini adalah siswa dapat merencanakan karir (Hidayati, Novi Wahyu, 2014).

Hasil penelitian Moch Fatoni A.S dan Moch Nursalim dengan judul penelitian "Pengembangan Materi Layanan Informasi Studi Lanjut Melalui Media Web Server Di Kelas VIII C SMP Negeri 1 Prambon". Hasil penelitiannya diperoleh 4 dari validasi yang menunjukkan bahwa materi layanan informasi studi lanjut melalui media Web Server memenuhi kriteria kelayakan dengan skor total $88 \%$. Skor tersebut diperoleh dari hasil uji ahli materi, ahli media dan praktisi serta siswa, Media ini dikategorikan sangat baik dan tidak perlu direvisi. Dengan demikian materi layanan informasiu studi lanjut melalui media Web Server layak digunakan dan dikembangkan pada siswa SMP Negeri 1 Prambon (A.S, Moch Fatoni, dan Moch Nursalim, 2014). Hasil penenelitian Nofa Dwi Handono dan Titin Indah Pratiwi dengan judul "Pengembangan Materi Layanan Informasi Studi Lanjut Melalui Media Blog Di SMA Negeri 4 Bojonegoro. Hasil yang didapat dalam penelitiannya dari segi materi mencapai $75 \%$ dikategorikan baik, segi media mencapai $83.3 \%$ dikategorikan baik sekali, sudut pandang praktisi mencapai 80\% dikategorikan baik sekali dan uji lapangan mencapai 91.7\% dikategorikan baik sekali. Sehingga, produk yang berisikan materi berupa informasi studi lanjut melalui sebuah media blog layak digunakan sebagai alat pemberian informasi (Handono, Nofa Dwi, dan Titin Indah Pratiwi. 2013).

Pemberian layanan informasi merupakan bagian dari layanan yang penting diberikan kepada siswa untuk menentukan studi lanjut dan orientasi karir kedepannya. Mengingat Salah satu tugas perkembangan remaja adalah mempersiapkan kelanjutan studi atau karir. Remaja disini adalah siswa SMA yang harus mempunyai rencana terhadap karirnya. Hal ini sangatlah 
penting bagi siswa untuk memudahkannya dalam menentukan arah studi yang akan diambil. Apabila siswa tidak dengan baik merencanakan karirnya, maka akan berdampak tidak baik bagi pilihannya terhadap studi lanjut. Perencanaan karir adalah sebagai proses yang dilalui sebelum pemilihan karir. Sering kali terjadi kesalahan dalam mengambil pilihan karena adanya beberapa faktor, baik faktor internal maupun faktor eksternal. Salah satunya adalah kurang nya informasi tentang studi lanjut. Hal ini sering terjadi pada siswa SMA yang akan menentukan rencana karirnya untuk masa depan yang lebih baik. Peraturan pemerintah mengemukakan bahwa standar kompetensi lulusan pada satuan pendidikan menengah umum bertujuan untuk meningkatkan kecerdasan, pengetahuan, akhlak mulia, serta ketrampilan untuk mandiri dan mengikitu pendidikan lebih lanjut. Hal ini menunjukkan bahwa siswa SMA harus mempersiapkan diri untuk karirnya kedepan yang sesuai dengan bakat dan minatnya. Karena masih banyak siswa yang tidak sesuai dalam menentukan studi lanjut sehingga berdampak tidak baik pada perencanaan karirnya. Sering terjadi kesalahan dalam perencanaan karir karena kurang mendapat informasi tentang studi lanjut. Salah satu contohnya banyak nya siswa yang ikut-ikutan dalam menentukan studi lanjut.

Berdasarkan hasil studi pendahuluan didapatkan data bahwa minat siswa melanjutkan studi ke perguruan tinggi masih rendah, dilihat dari faktor minimnya informasi mengenai studi lanjut, siswa belum dapat menentukan pilihan studi lanjut dan belum optimalnya layanan informasi yang diberikan oleh guru BK dikarenakan kurang optimalnya pemberian layanan selama pandemi. . Banyak siswa yang masih bingung tentang studi lanjut dan tidak mengerti arah dari sekolah lanjutan yang berhubungan dengan perencanaan karirnya. Berdasarkan wawancara dengan siswa, banyak siswa yang belum memahami kemampuan dirinya sendiri, kurangnya informasi dan mendapatkan informasi yang berbeda-beda, sehingga membuat siswa tersebut menjadi bingung. Hal ini sangatlah tidak baik terjadi pada siswa, karena akan berpengaruh pada masa depannya. Terkait dengan fenomena tersebut, peneliti ini ingin lebih lanjut meneliti terkait efektivitas layanan informasi melalui daring terhadap peningkatan minat studi lanjut ke perguruan tinggi khususnya pada siswa SMA N 3 Sukoharjo. 


\section{METODE}

Penelitian ini menggunakan desain yaitu pre-eksperimental design jenis one group pre-test post-test design. Desain penelitian one group pre-test post-test design diukur dengan menggunakan pre-test yang telah dilakukan sebelum diberi perlakuan dan post-test yang dilakukan setelah diberi perlakuan. Penelitian ini diberikan pada satu kelompok saja tanpa adanya kelompok pembanding. Untuk melaksankan metode ini, penelitian dilakukan terhadap satu kelas dan dengan adanya pre-test dan post test dapat memperlihatkan perbedaan sebelum dan sesudah perlakuan (treatment) diberikan.Penelitian ini mengambil populasi yakni kelas XI SMA N 3 Sukoharjo Tahun Pelajaran 2020/2021 yang berjumlah 355 siswa dan dalam penelitian ini mengambil sampel penelitian pada kelas XI MIPA 3 SMA Negeri 3 Sukoharjo Tahun Pelajaran 2020/2021 yang berjumlah 36 siswa karena menggunakan teknik random sampling menjadikan satu kelas sebagai sampel penelitian dari populasi yang ada.

Dalam penelitian ini digunakan metode non tes yaitu menggunakan skala psikologis. Adapun skala psikologi yang digunakan dalam penelitian ini adalah skala minat siswa untuk melanjutkan studi ke Perguruan Tinggi. Pengukuran dilakukan dua tahap, yaitu tahap pertama untuk mengetahui minat siswa untuk melanjutkan studi ke Perguruan Tinggi sebelum mendapatkan layanan informasi secara daring, dan tahap kedua untuk mengetahui minat siswa untuk melanjutkan studi ke Perguruan Tinggi setelah mendapatkan layanan informasi secara daring. Melalui metode pengumpula data dengan skala psikologi diatas jawaban responden akan mudah untuk ditabulasi, hasil tabulasi akan mempermudah menganalisis data, setelah mengetahui analisis data akan dibuat kesimpulan hasil penelitian. Sebelum skala psikologi ini digunakan terlebih dahulu dilakukan uji coba item pernyataan didalam skala psikologi tersebut sehingga mendapatkan angket yang valid dan reliable.

Penggunaan analisa data statistik pada penelitian ini menggunakan uji Paired Sample T-Test pada Pre Test dan Post Test. Uji Paired Sample T-Test adalah pengujian yang digunakan untuk membandingkan selisih dua mean dari dua sample yang berpasangan dengan asumsi data berdistribusi normal. Sampel berpasangan berasal dari subjek yang sama setiap variabel diambil saat situasi dan keadaan yang berbeda. Pengambilan keputusan dalam penelitian ini menggunakan bantuan program SPSS (Statistical Product and Service Solutions) versi 26 for windows. 


\section{HASIL}

Gambaran Minat Siswa Untuk Melanjutkan Studi ke Perguruan Tinggi Sebelum Dilaksanakan Layanan Informasi

Dari tabel 1 dapat diketahui gambaran minat siswa tentang perguruan tinggi sebelum diberikan layanan informasi:

Tabel 1 Distribusi Frekuensi Metode Sorogan (Variabel X)

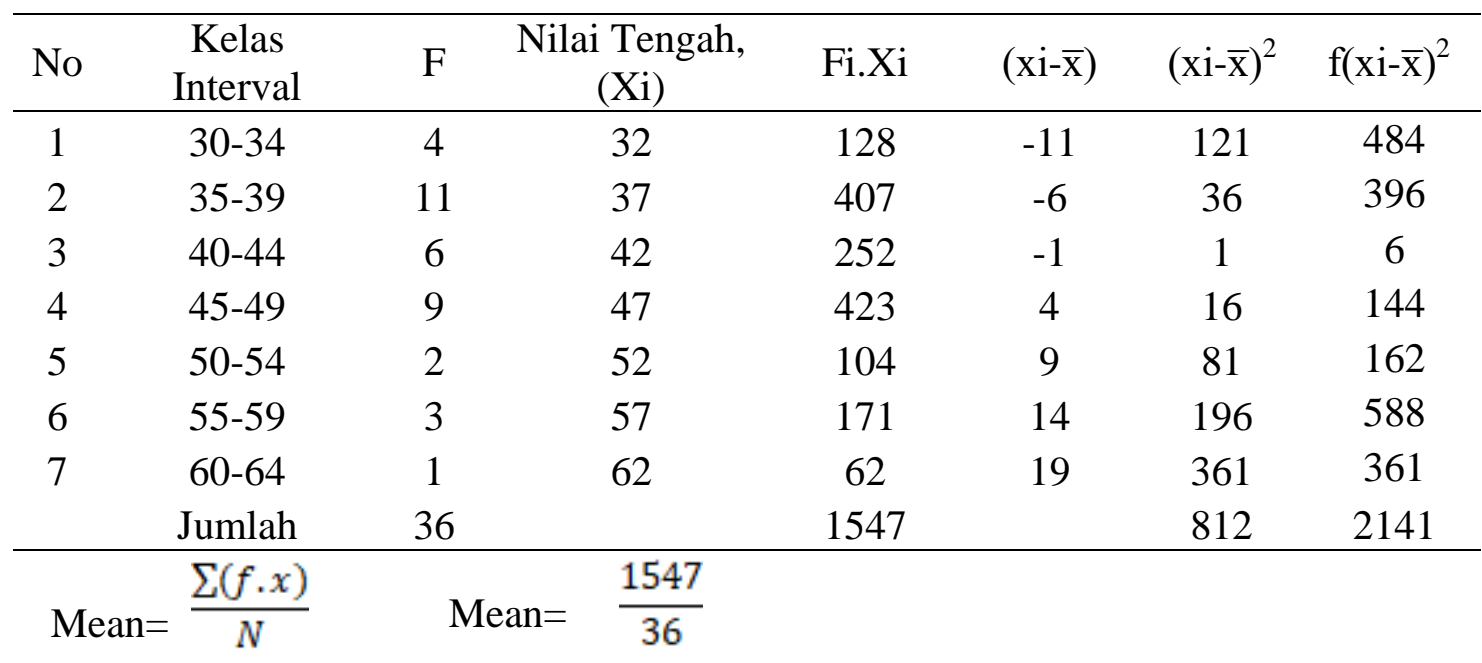

Mean $=42,97$

Dari hasil skala psikologi pre test yang telah disebarkan kepada 36 siswa kelas XI MIPA 3 SMA Negeri 3 Sukoharjo, dapat diperoleh skor tertinggi=60, skor terendah=30. Dengan mean atau rata-rata=42,97. Sehingga melihat dari rata-rata tersebut dapat diketahui 15 siswa memiliki minat yang tinggi untuk melanjutkan studi ke Perguruan Tinggi, 6 siswa memiliki minat sedang untuk melanjutkan studi ke Perguruan Tinggi, dan 15 siswa yang memiliki minat rendah untuk melanjutkan studi ke Perguruan Tinggi. 
Berdasarkan data yang telah diuraikan dihalaman sebelumnya, dapat dibuat grafik histogram sebagai berikut:

\section{Grafik 1}

\section{Hasil Pre Test Minat Siswa Untuk Melanjutkan Studi ke Perguruan Tinggi}

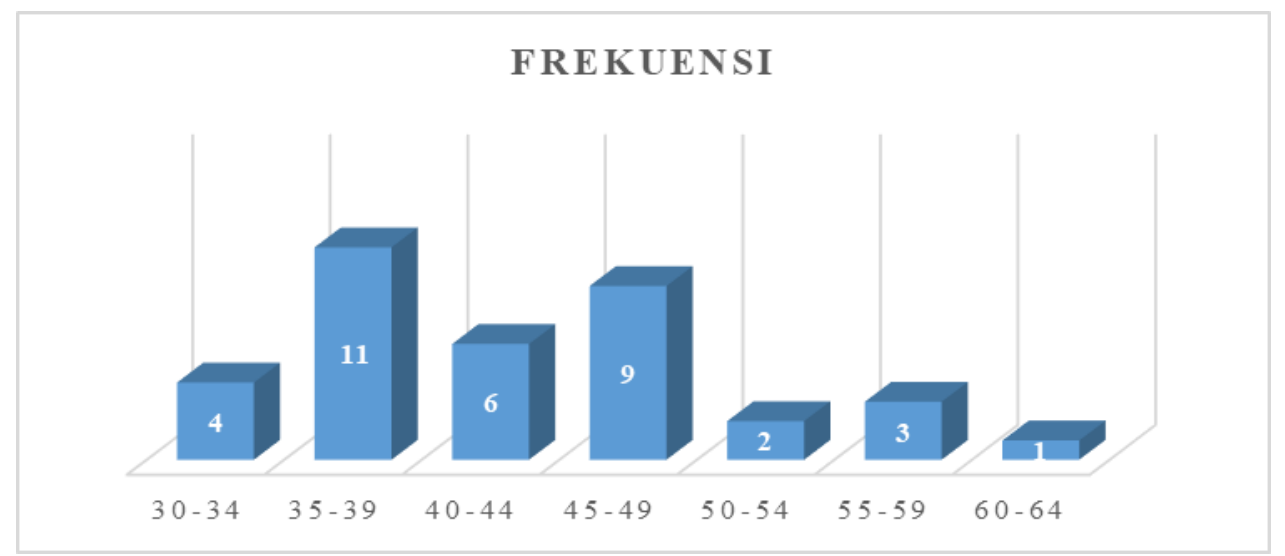

\section{Proses pelaksanaan layanan informasi secara daring tentang studi lanjut ke Perguruan}

\section{Tinggi}

Proses pemberian layanan informasi secara daring mengenai minat siswa tentang studi lanjut ke Perguruan Tinggi dilakukan selama dua kali pertemuan. Pada awal pertemuan pertama sampai akhir dihari kedua siswa sangat antusias untuk mengikuti materi yang akan diberikan. Pada pertemuan pertama siswa diberi materi tentang minat, pengertian Perguruan Tinggi, bentuk-bentuk Perguruan Tinggi, profil lembaga Tes Masuk Perguruan tinggi, fungsi dan tujuan Lembaga Tes Masuk Perguruan Tinggi. Mereka dapat mengikuti dengan baik pada pertemuan pertama ini dan suasana kelas online pada aplikasi google meet pun lancar tanpa ada gangguan koneksi. Pada pertemuan kedua sampai selanjutnya siswa diberikan materi tentang jalur dan kuota masuk Perguruan Tinggi, macam jian Tulis Berbasis Komputer (UTBK) dan materi tesnya, deskripsi SNMPTN dan SBMPTN serta tahapan tahapan tesnya. Pada setiap prosesnya seluruh siswa kelas XI MIPA 3 SMA Negeri Sukoharjo mengikuti dengan baik. Setelah proses layanan dilakukan tahap demi tahap atau dari pertemuan pertama sampai kedua, dapat dilihat bahwa siswa memiliki minat lebih untuk melanjutkan ke Perguruan Tinggi yang mereka inginkan. 
Gambaran Minat Siswa Untuk Melanjutkan Studi ke Perguruan Tinggi Setelah Dilaksanakan Layanan Informasi.

Tabel 2 Distribusi Frekuensi Metode Sorogan (Variabel X)

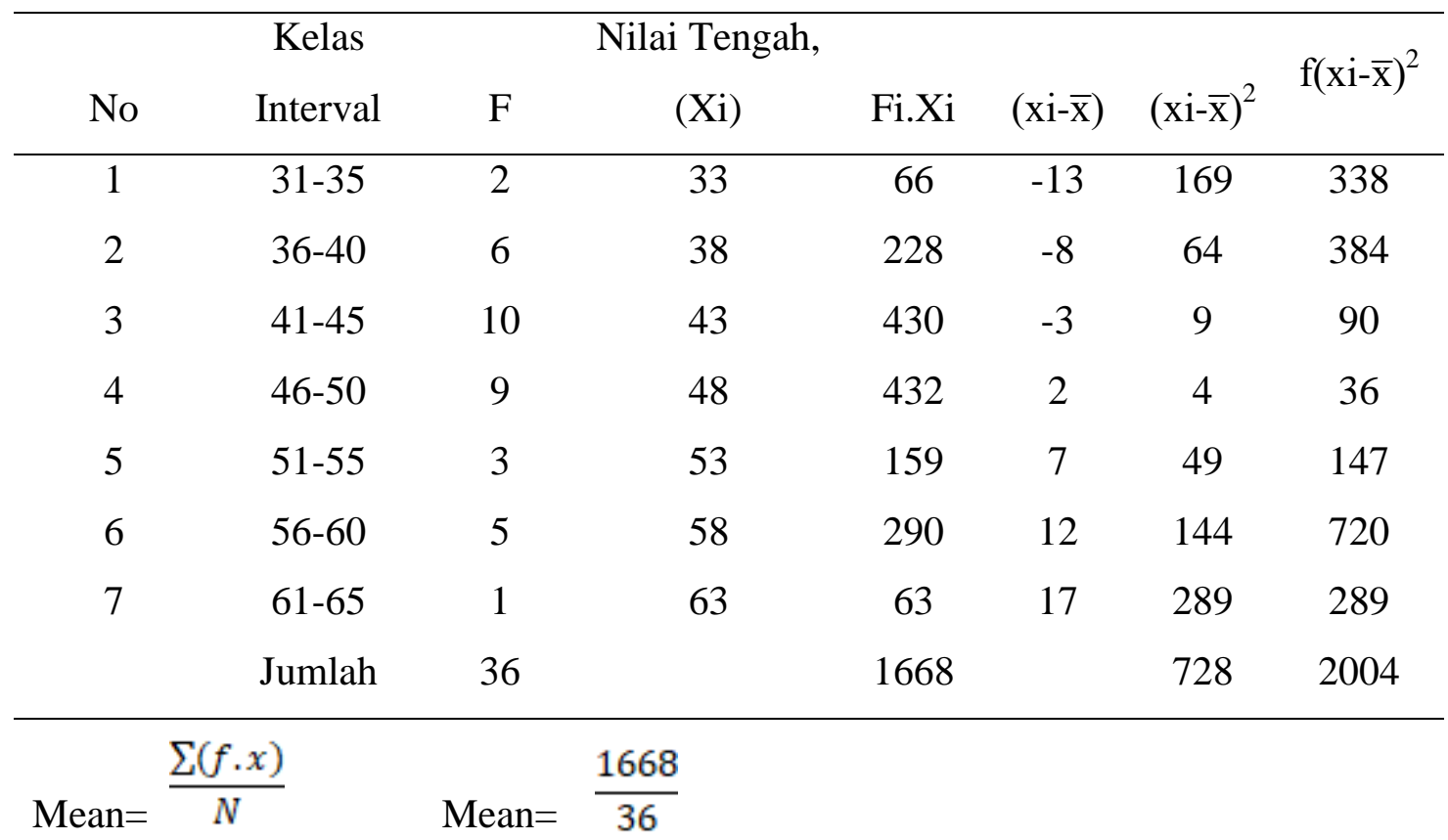

Mean=46,33 (dibulatkan menjadi 46)

Dari Perhitungan di atas, diperoleh mean (nilai rata-rata) $=46,33$.

Dari hasil skala psikologi post test yang telah disebarkan kepada 36 siswa kelas XI MIPA 3 SMA Negeri 3 Sukoharjo, dapat diperoleh skor tertinggi adalah 61, skor terendah adalah 31. Dengan mean atau rata-rata yaitu 46,33. Sehingga melihat dari rata-rata tersebut dapat diketahui 18 siswa memiliki minat yang tinggi untuk melanjutkan studi ke Perguruan Tinggi, 10 siswa memiliki minat sedang untuk melanjutkan studi ke Perguruan Tinggi, dan 8 siswa yang memiliki minat rendah untuk melanjutkan studi ke Perguruan Tinggi. 
Berdasarkan data yang telah diuraikan dihalaman sebelumnya, dapat dibuat grafik histogram sebagai berikut :

\section{Grafik 2}

\section{Hasil Post Test Minat Siswa Untuk Melanjutkan Studi ke Perguruan Tinggi}

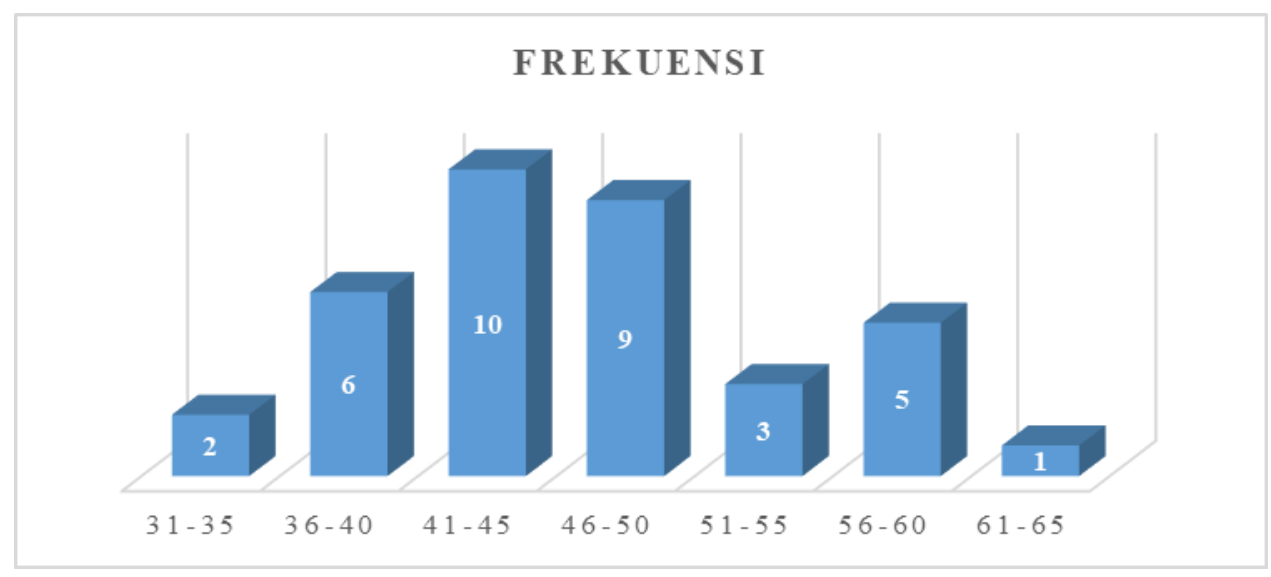

\section{PEMBAHASAN}

Pengaruh Layanan Informasi Melalui Daring Terhadap Peningkatan Minat Studi

\section{Lanjut Ke Perguruan Tinggi Pada Siswa Sma N 3 Sukoharjo}

Tabel 3.

Perhitungan SPSS uji Paired Sample T-Test pada Pre Test dan Post Test

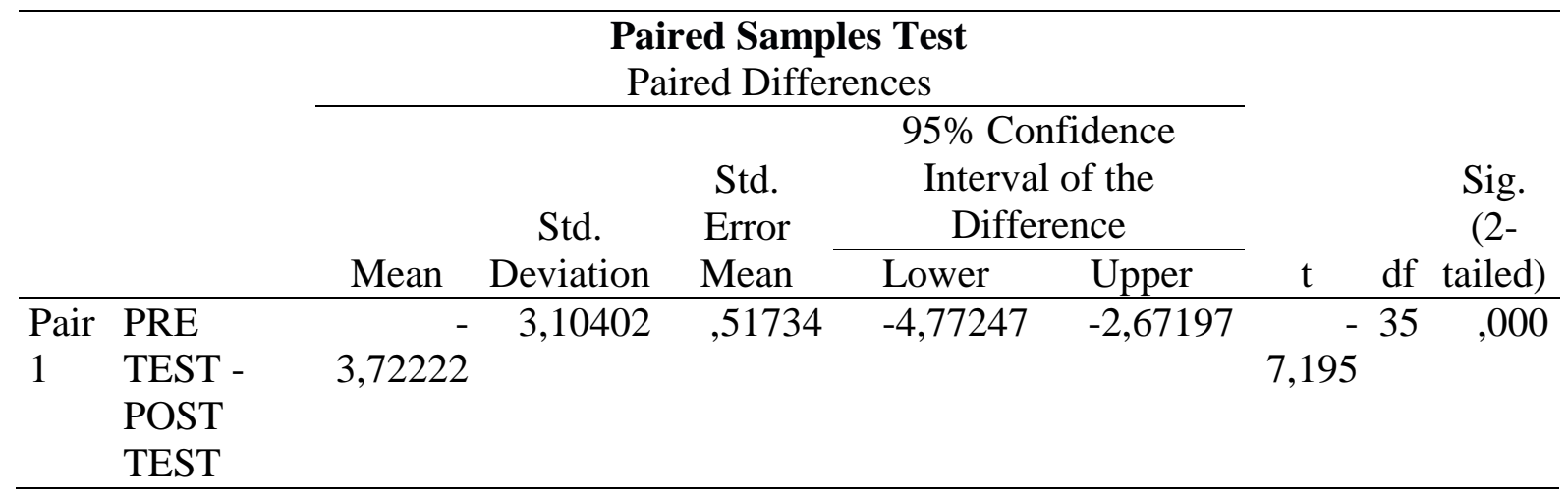

Hasil penelitian dengan menggunakan perhitungan uji Paired Sample T-Test pada Pre Test dan Post Test menunjukkan nilai Signifikansi (2-tailed) 0,000 $<0,05$, artinya menunjukkan adanya perbedaan yang signifikan antara variabel awal dengan variabel akhir. Ini menunjukkan terdapat pengaruh yang bermakna terhadap perlakuan yang diberikan pada masing-masing variabel. Sehingga dapat disimpukan bahwa: "Terdapat pengaruh pemberian layanan informasi secara daring mengenai studi lanjut terhadap minat siswa kelas XI MIPA 3 
SMA Negeri 3 Sukoharjo tahun pelajaran 2020/2021 untuk melanjutkan pendidikanya ke Perguruan Tinggi”. Hal tersebut artinya setelah diberikan layanan informasi secara daring dengan sebelum diberikan layanan informasi, artinya ada peningkatan minat siswa untuk melanjutkan studi ke Perguruan Tinggi yang signifikan. Setelah diberikan layanan informasi, siswa dengan mudah menempatkan minatnya masing-masing sesuai dengan keinginan dan jurusan-jurusan yang ada di perguruan tinggi.

Hal ini didukung oleh teori layanan informasi yang dikemukakan oleh Suhertina, (2014:117), bahwa layanan informasi sebagai layanan Bimbingan dan Konseling dapat memungkinkan siswa menerima dan memahami berbagai informasi seperti informasi pendidikan dan informasi jabatan serta informasi tersebut dapat dijadikan sebagai bahan pertimbangan dan pengambilan keputusan untuk kepentingan siswa dimasa depan.Sangat tepat jika memberikan informasi lebih awal pada siswa SMA karena sesuai dengan teori perkembangan Hurlock, peserta didik SMA berada pada usia remaja yaitu 14-17 tahun dimana pada rentang usia tersebut seseorang mulai mencari identitas dirinya dalam hal ini menyangkut aspek fisik, emosi, intelektual, sosial, dan moral-spritual (Hurlock, 2001). Pada aspek perkembangan intelektual, seorang peserta didik SMA/sederajat memiliki tugas perkembangan karir yaitu menentukan studi lanjutnya ke Perguruan Tinggi.

Pada tahap pemberian layanan informasi, siswa diberikan informasi yang bersifat terkini dan sesuai dengan kebutuhan, agar siswa dapat merencanakan secara matang pilihan yang akan mereka buat, kalaupun mereka berkeinginan untuk merubah apa yang telah mereka rencanakan sebelumnya, siswa sudah mendapatkan gambaran dan informasi yang jelas sehingga tidak terdapat lagi siswa yang merasa salah jurusan atau tidak meneruskan pendidikan ke jenjang yang lebih tinggi di karenakan tidak diterima SPMB ataupun faktor biaya, karena siswa telah mendapatkan informasi yang memadai tentang universitas terbuka yang memberikan kemudahan dalam menempuh pendidikan lanjut. Secara keseluruhan siswa sangat antusias dalam menerima layanan informasi, terkait pemberian materi tentang karena siswa ternyata belum mengenal atau mendapatkan informasi tentang Bentuk-bentuk Perguruan Tinggi, Profil lembaga Tes Masuk Perguruan tinggi, Fungsi dan Tujuan Lembaga Tes Masuk Perguruan Tinggi, Jalur dan Kuota masuk Perguruan Tinggi, Macam Ujian Tulis Berbasis Komputer (UTBK) dan Materi tesnya, Deskripsi SNMPTN dan SBMPTN serta tahapan tahapan tesnya 


\section{SIMPULAN}

Berdasarkan hasil analisis dan pembahasan sebagaimana dipaparkan di bab sebelumnya, maka dapat ditarik kesimpulan sebagai berikut:

1. Gambaran minat studi lanjut sebelum diberikan layanan informasi menunjukkan tingkat yang rendah, setelah diadakan hasil uji pre test menggunakan skala psikologi yang sudah diuji validitas dan sudah diolah menggunakan menggunakan perhitungan tabel distribusi frekuensi.

2. Gambaran minat studi lanjut setelah diberikan layanan informasi menunjukkan tingkat yang tinggi, atau dengan kata lain ada peningkatan antusias minat siswa untuk melanjutkan studi ke Perguruan Tinggi setelah mendapat layanan informasi secara daring dari Peneliti.

3. Kemudian dari hasil perbandingan hasil pre test dan post tes dengan menggunakan perhitungan uji Paired Sample T-Test pada Pre Test dan Post Test menunjukkan terdapat pengaruh yang bermakna terhadap perlakuan yang diberikan pada masingmasing variabel. Sehingga dapat disimpukan bahwa: "Terdapat pengaruh pemberian layanan informasi secara daring mengenai studi lanjut terhadap minat siswa kelas XI MIPA 3 SMA Negeri 3 Sukoharjo tahun pelajaran 2020/2021 untuk melanjutkan pendidikanya ke Perguruan Tinggi”

\section{DAFTAR RUJUKAN}

A.S, Moch Fatoni, dan Moch Nursalim. 2014. Pengembangan Layanan Informasi Studi Lanjut Melalui Media Web Server Di Kelas Viii C Smp Negeri 1 Prambon. Jurnal BK. Vol. 04 No. 03.

Arikunto, Suharsimi. 2010. Prosedur Penelitian Suatu Pendekatan Praktik. Jakarta: Rineka Cipta.

Aryani, Farida dan Muh. Rais. 2018. Bimbingan Karir Masa Depan Untuk Meraih Sukses Ke Perguruan Tinggi. Makassar: Badan Penerbit Universitas Negeri Makassar Makassar.

Azwar, Saifuddin. 2012. Penyusunan Skala Psikologi. Jogyakarta: Pustaka Pelajar.

Endriani, Ani dan Maemunah. 2016. Pengaruh Layanan Informasi Terhadap Kemampuan Merencanakan Studi Lanjut Bagi Siswa Kelas IX SMPN 3 Pringgabaya Kabupaten Lombok Timur Tahun Pelajaran 2014/2015. Jurnal Realita Vol. 1 No. 1.

Gunawan, Yusuf. 1987. Pengantar Bimbingan dan Konseling. Jakarta: Gramedia Pustaka Utama.

Handono, Nofa Dwi, dan Titin Indah Pratiwi. 2013. Pengembangan Materi Layanan Informasi Studi Lanjut Melalui Media Blog Di Sma Negeri 4 Bojonegoro. Jurnal Bimbingan Konseling Vol. 04, No. 01.

Hardani, dkk. 2020. Metode Penelitian Kualitatif \& Kuantitatif. Yogyakarta: CV. Pustaka Ilmu. 
Hidayati, Novi Wahyu. 2014. Pengaruh Layanan Informasi Studi Lanjut Terhadap Perencanaan Karir Siswa. Jurnal Edukasi, Vol. 1, No. 1.

Inanna. 2018. Peran Pendidikan Dalam Membangun Karakter Bangsa Yang Bermoral. Jurnal Ekonomi dan Pendidikan Vol. 1 No. 1.

Iskandar. 2012. Psikologi Pendidikan. Ciputat: Gaung Persada Press.

Khadijah, Siti, dkk. 2017. Analisis Minat Peserta Didik untuk Melanjutkan Pendidikan Tinggi. Jurnal Pendidikan Ilmu Sosial Vol. 26, No. 2.

Kurniawan, Agung Widhi, dan Zarah Puspitaningtyas. 2016. Metode Penelitian Kuantitatif. Yogyakarta: Pandiva Buku.

Listianah dan H. Muhari. 2013. Penerapan Layanan Informasi Dengan Menggunakan Media Movie Maker Untuk Meningkatkan Pemahaman Memilih Studi Lanjut Pada Siswa Kelas XII Di Sma Negeri 3 Lamongan. Jurnal Mahasiswa Bimbingan Konseling, Vol. 1 No. 1.

Mulyono, dkk. 2015. Pengaruh Layanan Informasi Terhadap Peningkatan Minat Siswa Tentang Perguruan Tinggi Kelas XI Farmasi Ikasari Pekanbaru. Jurnal Bimbingan Konseling.

Munira, Nur. 2017. Faktor-Faktor Yang Mempengaruhi Minat Siswa Madrasah Aliyah Negeri (Man) 2 Jembrana Kelas XII Untuk Melanjutkan Studi Ke Perguruan Tinggi Pada Tahun Ajaran 2017/2018. Jurnal Pendidikan Ekonomi Undiksha Vol. 9 No.2.

Muttaqin, Reza, dkk. 2017. Keefektifan Layanan Informasi Karier Berbantuan Video Interaktif dan Live Modeling untuk Meningkatkan Pemahaman Karier Siswa SMP. Jurnal Bimbingan Konseling Vol. 6, No. 2.

Nasution, Henni Syafriana dan Abdillah. 2019. Bimbingan Konseling "Konsep, Teori dan Aplikasinya”. Medan: Lembaga Peduli Pengembangan Pendidikan Indonesia (LPPPI).

Pohan, Albert Efendi. 2020. Konsep Pembelajaran Daring Berbasis Pendekatan Ilmiah. Purwodadi: CV Sarnu Untung.

Prayitno dan Erman Amti. 2013. Dasar-Dasar Bimbingan Dan Konseling. Jakarta: Rineka Cipta.

Prayitno. 2004. Layanan Informasi. Padang: Fakultas Ilmu Pendidikan Universitas Padang.

Purwoko, Budi. 2008. Organisasi dan Managemen Bimbingan Konseling. Surabaya: Unesa University Press.

Saifudin, Azwar. 2007. Metode Penelitian. Yogyakarta: Pustaka Pelajar.

Setyosari, Punaji. 2012. Metode Penelitian Pendidikan dan Pengembangan. Jakarta: Kencana.

Sugiyono. 2017. Metodologi Penelitian Pendidikan. Bandung: Alfabet.

Suhertina. 2014. Dasar-Dasar Bimbingan dan Konseling. Pekanbaru: CV Mutiara Pesisir Sumatra.

Sujarweni, Wiratna. 2014. SPSS untuk Penelitian. Yogyakarta: Pustaka Baru Press.

Sukardi, Dewa K. 2003. Managemen Bimbingan dan Konseling di Sekolah. Bandung: Alfa Beta.

Sulistyarini dan Mohammad Jauhar. 2014. Dasar-Dasar Konseling Panduan Lengkap Memahami Prinsip- Prinsip Pelaksanaan Konseling. Jakarta: Prestasi Pustakaraya.

Sutikna, Agus. 1998. Bimbingan Karir Untuk SMA. Jakarta: Intan Pariwara.

Syafaruddin, dkk. 2019. Dasar-Dasar Bimbingan Dan Konseling Telaah Konsep Teori dan Praktik. Medan: Perdana Publishing.

Syahrum dan salim. 2012. Metodologi Penelitian Kuantitatif. Bandung: Citapustaka Media. 
Widoyoko, Eko Putro. 2014. Penilaian Hasil Pembelajaran di Sekolah. Yogyakarta: Pustaka Pelajar. 